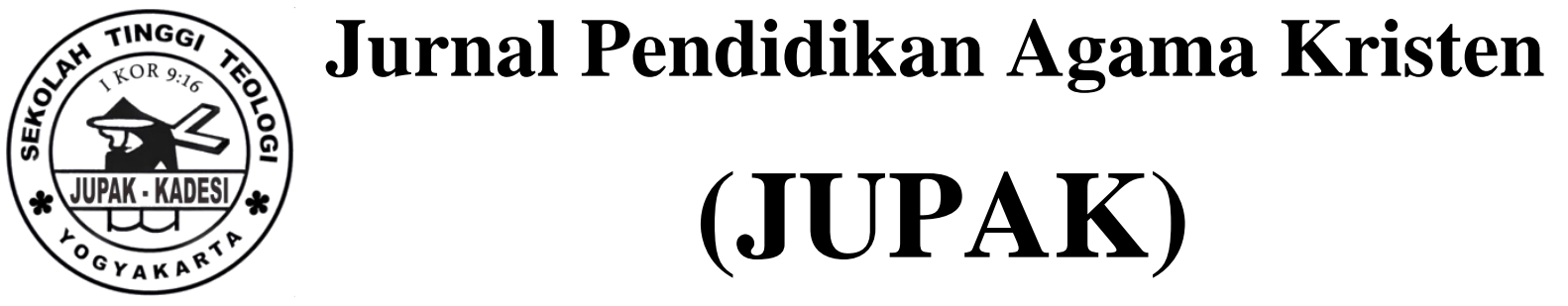

Vol. 2 No. 1 (December 2021) hlm. 13 - 35

Jurnal Pendidikan Agama Kristen (JUPAK)

e-ISSN 2774-3861

https://ejurnal.sttkadesiyogyakarta.ac.id/index.php/jupak

p-ISSN 2774-6399

\title{
https://doi.org/10.52489/jupak.v2i1.61
}

\section{Peran Fundamental Gembala Bagi Guru Saat Pandemik dalam Pembelajaran Online Berbasis Karakter: Tantangan dan Sistem Pendukung}

\author{
Janes Sinaga $^{1)^{*}}$, Rudolf Weindra Sagala ${ }^{2)}$, Rolyana Ferinia ${ }^{3)}$, Stimson \\ Hutagalung ${ }^{4)}$. \\ )*Progam Pasca Sarjana Universitas Advent Indonesia, Bandung, janessinaga777@gmail.com.
}

\section{Recommended Citation}

Turabian $8^{\text {th }}$ edition (full note)

Janes Sinaga et al., "Peran Fundamental Gembala Bagi Guru Saat Pandemik dalam Pembelajaran Online Berbasis Karakter: Tantangan dan Sistem Pendukung." Jurnal Pendidikan Agama Kristen (JUPAK) 2, no 1 (December 03, 2021): 1, accessed December 8, 2021, https://ejurnal.sttkadesiyogyakarta.ac.id/index.php/jupak/article/view/61.

American Psychological Association $7^{\text {th }}$ edition

(Sinaga, 2021, p.1).

Received: 26 September 2021 Accepted: 1 November 2021 Published: 03 December 2021

This Article is brought to you for free and open access by Sekolah Tinggi Teologi Kadesi Yogyakarta. It has been accepted for inclusion in Christian Perspectives in Education by an authorized editor of Jurnal Pendidikan Agama Kristen (JUPAK).

For more information, please contact juniorichson1995@gmail.com 


\begin{abstract}
The purpose of this paper is to describe the fundamental role of a pastor in a church that has a school, especially to teachers who are facing challenges and problems implementing spiritual matters in online learning. This study used a qualitative method with a descriptive approach. Data collection techniques using literature studies, using references from various library sources and journals. Interviews were conducted to corroborate the analysis and statements. As a result, the fundamental role of the pastor during the covid-19 pandemic is very crucial for teachers in the spiritual field, by providing pastoral care for teachers who are experiencing stress, praying for them specifically one by one, helping to teach students about Christian Religious Education as a whole that equipped with short worship, group prayer, and Bible reading as literacy.
\end{abstract}

Keywords: Shepherd, Teacher, Pandemic, School.

\begin{abstract}
Abstrak
Tujuan penulisan ini adalah memaparkan peran fundamental seorang gembala jemaat di gereja yang memiliki sekolah, terutama kepada guru-guru yang sedang menghadapi tantangan dan masalah mengimplementasikan hal kerohanian di pembelajaran online. Penelitian ini menggunakan metode kualitatif dengan pendekatan deskriptif. Teknik pengumpulan data menggunakan studi literatur, yaitu menggunakan referensi dari berbagai sumber pustaka dan jurnal. Wawancara dilakukan untuk menguatkan analisis dan pernyataan. Hasilnya, peran fundamental gembala disaat pandemi covid-19 sangat krusial bagi guru-guru di bidang kerohanian yaitu memberikan pendampingan pastoral bagi guru yang sedang mengalami stres, mendoakan mereka secara khusus satu persatu, membantu memberikan pengajaran kepada peserta didik tentang Pendidikan Agama Kristen secara menyeluruh yang dilengkapi dengan ibadah singkat, doa kelompok, dan pembacaan Alkitab sebagai literasi.
\end{abstract}

Kata kunci: Gembala, Guru, Pandemi, Sekolah.

\title{
PENDAHULUAN
}

Berdirinya gereja seringkali dilakukan secara bersamaan dengan pembangunan sekolah yang berada di satu kompleks. Salah satu tujuan pendirian sekolah oleh gereja supaya anak anggota gereja dapat bersekolah di sekolah tersebut untuk pengembangan kerohanian yang optimal. Sebagai umat Tuhan sudahlah menjadi keharusan memilih sekolah dengan tepat untuk pengembangan pendidikan pengetahuan dan kerohanian. Memilih sekolah dilakukan berdasarkan penilaian khusus, yaitu Tuhan adalah fondasinya. Saat merencanakan pendidikan anak di luar rumah, orang tua harus menyadari bahwa mengirim anak ke sekolah umum tidaklah aman dan mereka harus berusaha keras untuk mengirim anaknya ke sekolah yang memasukan pengajaran Alkitab sebagai mata pelajaran yang wajib. Semua orang tua yang beriman memiliki tanggung jawab yang sungguh-sungguh untuk mendidik anak-anak mereka agar memperoleh pengetahuan ilahi dan menjadi bagian dari sifat-sifat Tuhan dengan mengikuti kehendak dan sikap-Nya (White, 2005). 
Pemilihan sekolah gereja atau sekolah Kristen merupakan pilihan yang sangat tepat. Hal ini dikarenakan mereka akan di didik oleh guru-guru yang takut akan Tuhan dan yang akan mengajarkan kebenaran Tuhan. Semua gereja seharusnya memiliki sekolah, dan guru di sekolah ini adalah pengkhotbah kebenaran. Guru perlu dilatih untuk memainkan peran dalam tugas penting untuk mendidik anak-anak pemelihara Sabat, tidak hanya dalam sains tetapi juga dalam Alkitab. Sekolah-sekolah seperti ini seharusnya didirikan di berbagai tempat, dijalankan oleh orang-orang yang bertakwa sesuai kebutuhan, dan harus didirikan dengan prinsip yang sama dengan Sekolah Nabi (White, 2005).

Sebuah gereja digembalakan oleh seorang pendeta. Peran gembala adalah memelihara anggota jemaat. Dia adalah seorang pengelola yang harus paham manajemen dan administrasi dan menjadi seorang administrator yang baik, mengerti manajemen risiko, manajemen administrasi, manajemen sumber daya manusia, dan terutama manajemen strategi. Dia juga menjadi seorang guru untuk mengajarkan kebenaran. Pendeta juga dituntut totalitas dalam melayani. Pendeta sebagai pelayan. Dilain sisi, pendeta terkadang sebagai terapis. Ketika anggota gereja ada yang sedang menghadapi masalah dan mengganggu kesehatan psikis, mental, rohani, dan tubuh, maka pendeta harus sanggup membuatnya lebih sehat secara psikis, mental, rohani, dan tubuh (Hutagalung, 2021). Peran yang diembannya bertujuan agar semua anggota jemaat dipenuhi kebutuhan rohani oleh gembala jemaat dan fokus penggembalaan haruslah berpusat dengan anggota jemaat dan gereja yang digembalakannnya.

Para peneliti di Indonesia sangat jarang melakukan penelitian yang membahas tentang peran seorang pendeta secara detail, tetapi ada beberapa penelitian yang membahas peran pendeta dari berbagai aspek. Seperti membahas tentang tugas dan tanggung jawab seorang pendeta. Gunter, (2018) lebih fokus kepada tugas untuk mengembangkan sistem teologis yang setia pada standar otoritatif Kitab Suci yang disesuaikan dengan kearifan lokal. Rummage, (2005) dalam penelitiannya membahas tentang kekhawatirannya atas tanggung jawab pengasuhan yang dibebankan kepada pendeta sehingga menimbulkan konsekuensi negatif bahwa pelayanan pastoral di gereja semata-mata berada dipundak pendeta professional. Dawa, (2020) lebih menekankan bahwa peran gembala jemaat adalah sebagai cendekiawan yang mampu merespons situasi dari keadaan gereja yang saat ini sudah kontemporer, tingginya sekularisasi, dan menjamurnya ideologi keagamaan yang berpusat pada diri sindiri. Dia juga melakukan penelitian lain tentang peran seorang pendeta tentang peran pendeta sebagai seorang figur sosial di masyarakat beragama dengan hasil penelitian

15 Jurnal Pendidikan Agama Kristen (JUPAK) Vol. 2 No. 1 December 2021 
bahwa tingkah laku seorang pendeta dituntut untuk dapat menyesuaikan diri dengan kebiasaan umum masyarakat, dan diharapkan pendeta dapat memenuhi standar umum yang telah ada pada masyarakat agama. Hanya ada satu penelitian tentang peran pendeta sebagai guru. Menurut Siew, (2013) tugas seorang pendeta adalah sebagai guru yang adaptif untuk membentuk budaya jemaat, membentuk iman, dan mempengaruhi visi pendidikan. Seorang pendeta yang efektif adalah seorang gembala-guru adaptif, yang memandang pembentukan iman sebagai terintegrasi dalam kehidupan total jemaat dan secara kreatif membentuk pelayanan inti menjadi pengalaman pembentukan iman.

Dari beberapa penelitian tersebut terlihat jelas bahwa pembahasan masih bersifat umum, peran dan tanggung jawab seorang pendeta di lingkungan jemaat/gereja, tetapi masih belum ada penelitian yang membahas tentang peran seorang pendeta yang menjadi gembala di gereja dan yang memiliki sekolah gereja. Oleh sebab itu, penelitian ini dilakukan untuk menganalisis secara literatur sejauh mana peran gembala dalam mendukung guru di sekolah gereja, terutama di masa Pandemi Covid-19.

Di masa pandemi ada banyak orang mengalami kendala, baik di dalam pekerjaan dan Pendidikan. Di dunia Pendidikan guru juga sangat terdampak. Guru-guru di sekolah memiliki masalah dan kesulitan dalam pengajaran dan ini dapat menyebabkan kendala dalam pengajaran yang dilakukan oleh guru. Menurut Rifai (2021) tekanan tugas dalam melakukan pembelajaran online menimbulkan stres bagi guru. Stres yang dialami guru selama pandemi ini bisa disebabkan oleh berbagai faktor, antara lain tekanan kerja, akibat pembelajaran online, dan risiko kematian akibat wabah penyakit. Pada masa pandemi guru-guru harus menjaga kesehatan agar tidak terpapar covid-19, namun beberapa guru tidak memiliki kemampuan mengajar lewat daring. Masalah lain timbul dari belajar secara daring, yang dimana murid sangat sulit di kontrol untuk serius dalam proses belajar sehingga materi tidak dapat disampaikan secara sempurna seperti pada waktu offline. Menurut Wahyuningsih (2021) Kendala lain yang dihadapi guru dan siswa yaitu perubahan mendadak sistem pembelajaran dari pembelajaran tradisional ke pembelajaran online (akibat pandemi covid19) tentunya berdampak pada para guru dalam mempersiapkan materi pembelajaran, model, dan metode yang digunakan. Tidak jarang para guru berjuang untuk menguasai teknologi informasi. Sehingga proses pembelajaran tidak berjalan dengan maksimal. Sedangkan bagi siswa cenderung hadir dan kurang aktif dalam pembelajaran, yang dapat mengakibatkan kurangnya motivasi, kurang konsentrasi dan berdampak pada prestasi belajar . Lebih lanjut Rifai (2021) menjelaskan bahwa tekanan pada seseorang, terlepas dari apakah stres itu dalam 
bentuk beban kerja, situasi keluarga, ekonomi, wabah penyakit, atau apa pun yang membuat seseorang dapat merasakan tekanan untuk menyelesaikannya. Stres manusia disebabkan oleh ketidakseimbangan antara kemampuan dan kekuatan. Dengan adanya masalah baru serta tekanan yang dihadapai oleh para guru sekolah tersebut maka gembala jemaat sebagai mitra kerja di sekolah dalam bidang kerohanian harus dapat menolong mereka dalam meringankan beban yang di alami.

\section{METODE PENELITIAN}

Penelitian ini menggunakan metode kualitatif dengan pendekatan deskriptif. Teknik pengumpulan data menggunakan studi literatur, yaitu menggunakan referensi dari berbagai sumber Pustaka dan jurnal (Ristiono \& Sirait, 2021, p. 189). Wawancara dilakukan untuk menguatkan beberapa pernyataan. Penelitian ini mengkaji setiap masalah dan pendapat ahli yang ditemukan dari berbagai sumber seperti jurnal, buku-buku dari perpustakaan umum, wawancara dengan kepala sekolah dan pengalaman pribadi sebagai seorang gembala jemaat dan guru Pendidikan Agama Kristen di SD dan SMP Advent Banjarmasin Kalimantan Selatan. Subjek penelitian ini adalah sekolah gereja Masehi Advent Hari Ke Tujuh yang berada di kota Banjarmasin. Sasaran yang akan dicapai dalam penelitian ini untuk mengetahui peran fundamental seorang gembala di gereja dalam mengambil bagian pelayanan di sekolah.

\section{HASIL DAN PEMBAHASAN}

\section{Pentingnya Sekolah Gereja}

Salah satu misi strategis gereja adalah mendidik atau melatih umat dan jemaat. Gereja adalah pusat pendidikan. Segala sesuatu yang berhubungan dengan pendidikan harus didasarkan pada pengembangan iman dalam jemaat (Nadeak \& Hidayat, 2017). Sekolah gereja adalah sebuah sekolah yang didirikan dengan inisiatif Majelis Gereja, dimana sekolah gereja adalah tempat anak-anak untuk mendapatkan Pendidikan kerohanian bersamaan dengan pendidikan ilmu pengetahuan umum. Sekolah gereja dikenal juga dengan sebutan sekolah Kristen. Dengan adanya sekolah gereja tentunya seorang anak akan lebih mudah dan mendalam mengenal Allah sebagai Tuhan dan pencipta. Sekolah Gereja merupakan lembaga pendidikan swasta formal yang berlandaskan iman kristiani. Jenis dan jenjangnya dalam sekolah ini tergantung pada jenjang sekolah dalam sistem pendidikan nasional (Weinata Sairin, 2006, p. 184). 
Menurut Simamora (2021) Sekolah Kristen adalah bagian dari pendidikan Kristen sebagai keluarga dan mitra gereja untuk memenuhi panggilan Tuhan kepada semua orang percaya. Prinsip dasar sekolah Kristen adalah iman Kristen yang dijelaskan dalam Alkitab. Oleh karena itu, sekolah Kristen menginginkan sesuatu yang disengaja dan terencana agar siswa dapat mengalami perubahan pengetahuan, sikap, nilai, dan keterampilan serta hidup dalam masyarakat sesuai dengan kehendak Tuhan. Tujuan utama sekolah Kristen adalah menyadarkan siswa akan Tuhan sebagai pribadi Yesus Kristus, tunduk pada otoritas Tuhan, dan hidup menurut kehendak Tuhan untuk kemuliaan Tuhan. Ciri khas sekolah Kristen adalah memenuhi kewajiban dan fungsinya dengan menekankan nilai-nilai iman kristiani untuk mewarnai proses pendidikan dan pembelajaran, dan nilai-nilai tersebut diwujudkan dalam semua materi dan sekolah Kristen yang disajikan. Hal ini adalah sesuatu yang tidak dimiliki oleh sekolah non-Kristen.

Pendidikan Kristen merupakan pondasi iman Kristen (Sunarko, 2021, p. 98). Pendidikan Kristen dapat dilakukan di lembaga sekolah Kristen. Sekolah adalah lembaga sosial tempat siswa belajar tentang dunia, tempat mereka harus hidup dan kewajiban panggilan mereka (Edlin, 2014). Sekolah-sekolah Kristen memiliki tujuan untuk mencerminkan pandangan dunia Alkitabiah (Van Brummelen, 2008). Semua upaya untuk memenuhi tujuan sekolah dan pendidikan perlu ada sebuah dasar atau titik acuan yang mendukung berjalannya pemenuhan tugas dari sekolah ini (Nadeak, 2017).

Setelah dosa masuk ke dunia maka dosa merusak setiap sistem yang ada didunia ini termasuk sistem pendidikan pertama yang di rancang dan di buat oleh Tuhan di taman Eden kepada Adam dan Hawa sehingga akibatnya sampai saat ini kemerosotan moral manusia, kecerdasan manusia menurun dan tabiat manusia menjadi rusak sehingga harus adanya pemulihan. Yesus telah mengadakan pemulihan melalui penebusan di kayu salib melalui pengorbanan-Nya untuk memulihkan gambar dan citra Allah yang telah rusak, maka di harapkan apa yang sudah di buat oleh Yesus harus di lanjutkan atau di pertahankan oleh setiap umat manusia di dunia ini. Untuk mencapai tujuan tersebut maka gereja melalui anggota jemaatnya mendirikan sekolah. Dimana sekolah tersebut mendidik tabiat anak selaras dengan Firman Tuhan.

Kebiasaan Kristen yang ideal adalah menjadi seperti Kristus. Di depan umat Tuhan, ada jalan kemajuan yang berkelanjutan. Umat Tuhan harus memiliki tujuan yang akan dicapai dan memiliki sarana untuk mencapainya. Ini termasuk semua yang baik, suci, mulia, 
dan tinggi. Harus ada usaha terus-menerus dan kemajuan terus-menerus untuk menuju kesempurnaan kebiasaan (Ellen G. White, 2005a, p. 116).

Menurut Kristina (2016) tujuan Pendidikan Agama Kristen di buat di sekolah untuk mengajak, menolong, dan mengutus anak-anak supaya dapat mengenal kasih Allah yang sejati dalam Tuhan Yesus Kristus. Jadi, di bawah bimbingan Roh Kudus, anak memasuki persekutuan dan membuatnya tinggal di dalam Allah. Ia mengekspresikan dirinya dalam kasih kepada Tuhan dan sesamanya yang diekspresikan dalam kehidupan sehari-hari. Dengan perkataan dan perbuatan sebagai anggota tubuh Kristus. Anak tidak hanya memenuhi kebutuhannya, tetapi juga mengalami perubahan pengetahuan dan perilaku.

Anak-anak harus mengetahui siapa Penciptanya dan bagaimana berperilaku sebagai anak yang takut akan Tuhan. Pendidikan ini bukan hanya didapatkan di Gereja maupun di rumah, namun juga dapat diperoleh di sekolah. Kristina (2016) menjelaskan bahwa perubahan yang terjadi pada anak dipengaruhi oleh segala sesuatu yang dialami dan dipelajarinya. Sebagai orang percaya, perubahan yang perlu terjadi adalah kehidupan yang semakin serupa dengan Kristus. Agar hal ini terjadi, anak harus dapat memahami siapa Penciptanya, siapa yang menyelamatkannya, dan siapa yang selalu bersamanya. Perubahan dimulai dengan pola berpikir tentang Tuhan. Hal ini memungkinkan anak-anak untuk percaya dan menerima Tuhan sebagai penguasa hidup mereka. Sikap yang didominasi Tuhan mengungkapkan gaya hidup Tuhan yang mulia.

\section{Peran Sekolah Gereja}

Sekolah gereja berusaha menerapkan pengajaran-pengajaran Ilahi sebagai suatu tujuan utama untuk mengembalikan gambar dan citra Allah yang telah rusak oleh karena dosa dengan membangun tabiat dan karakter peserta didik di bangku Pendidikan dan di ruangruang kelas. Melalui kasih dan belas kasihan Yang Mahakuasa, rencana penebusan dirancang dan kehidupan pencobaan diberikan. Memulihkan citra Penciptanya pada manusia, mengembalikannya sepenuhnya pada saat ia diciptakan, dan meningkatkan perkembangan tubuh, pikiran, dan jiwa sehingga tujuan ilahi penciptaannya terpenuhi dan inilah yang menjadi tujuan pendidikan dan tujuan besar dalam hidup ini (Ellen G. White, 2005b, p. 5).

Guru pendidikan agama Kristen menerima perintah ilahi melalui Firman Tuhan untuk membentuk kecerdasan spiritual anak-anak Kristen di lembaga pendidikan formal. Bagi para pendidik Kristen, upaya untuk melatih anak-anak Kristen dilakukan dengan mengenalkan Firman Tuhan sejak dini, mengajarkan doa, membiasakan beribadah kepada Tuhan, memberi 
teladan kasih, dan mempraktekkan kasih (Marthen Mau, Saenom, 2021). Hal-hal rohani tersebut dipraktekkan di ruang-ruang kelas sebelum memulai kelas mata pelajaran ataupun sesudah pengajaran dilakukan. Semua itu dilakukan dengan tujuan membentuk karakter siswa dengan baik.

\section{Peranan Guru Dalam Pengajaran Di Masa Pandemi Covid- 19}

\section{Pembelajaran Di Masa Pandemi Covid-19}

Pandemi Covid-19 telah merubah proses belajar dan mengajar. Ada fase saat awal pandemi dimana sekolah-sekolah sempat diliburkan dan segera setiap sekolah beradaptasi dengan terburu-buru, tidak direncanakan dan mengalihkan pembelajaran tatap muka menjadi pembelajaran daring. Pendidikan berubah secara dramatis. Pembelajaran jarak jauh dengan platform digital telah menjadi prioritas pengajaran. Sangat jelas pandemi ini telah benarbenar merubah sistem pendidikan. Dahulu, sekolah cenderung hanya fokus dengan pengajaran tradisional seperti hafalan, guru mengajar di depan kelas, murid-murid mendengarkan dan mencatat. Murid bertanya saat guru memberikan pertanyaan. Sekarang proses ini harus berubah dan dilakukan secara daring dengan metode yang lebih canggih.

Virus corona atau yang lebih dikenal dengan Covid-19 merupakan masalah global. Efek penyebaran virus tidak hanya mempengaruhi kesehatan masyarakat, tetapi juga ekonomi domestik dan internasional (Jolf John Tendean, Bartholomeus Diaz Nainggolan, 2021). Sebagai dampak dari pandemi COVID-19, berbagai kebijakan telah diterapkan untuk memutus mata rantai penyebaran virus COVID-19 di Indonesia. Salah satu upaya pemerintah Indonesia adalah menghimbau kepada masyarakat luas untuk menjaga jarak secara fisik, yaitu menjaga jarak antar orang, menjauhi segala bentuk keramaian dan aktivitas kelompok, serta menghindari pertemuan yang melibatkan banyak orang. Upaya ini ditujukan kepada masyarakat agar dapat dilakukan untuk memutus mata rantai penyebaran pandemi COVID-19 saat ini (Puspitasari, 2020).

Pembelajaran daring menjadi keharusan. Guru dan murid sama-sama harus beradaptasi secepat mungkin. Pembelajaran daring pada ahirnya merubah struktur pembelajaran. Perlu penyesuaian kebiasaan belajar, mencari teknik belajar yang tepat, dan beradaptasi dengan penggunaan perangkat komputer dan paham segala sesuatu tentang aplikasi dan jaringan. 


\section{Kendala Yang Dihadapi Pendidikan Di Masa Pandemi Covid 19}

Meskipun kita telah melakukan yang terbaik untuk beradaptasi, pandemi COVID-19 masih menghadapi banyak kendala di dunia pendidikan. Namun dalam situasi seperti ini, untuk mencerdaskan bangsa Indonesia perlu dilakukan proses pendidikan dan pembelajaran. Kemendikbud memberikan arahan sebagai berikut: Menyusul maraknya wabah Covid-19 di belahan bumi ini, sistem pendidikan mulai mencari inovasi dalam proses kegiatan pendidikan dan pembelajaran. Selain itu, Surat Edaran Menteri Pendidikan, Kebudayaan, Olahraga, Iptek Nomor 4 Tahun 20204 merekomendasikan agar semua kegiatan di lembaga pendidikan dihindari dan semua materi yang diberikan diantar ke rumah masing-masing (Teddy Meilwansyah, 2020).

Inovasi perlu dilakukan mulai dari inovasi-inovasi sederhana hingga yang canggih. Secara teknis, pembelajaran berbasis inovasi daring sangat berbeda dengan pembelajaran tradisional di sekolah, guru dan siswa tidak bertatap muka. Hal ini dilakukan dari jarak jauh agar guru dan siswa dapat bertemu di tempat yang berbeda dengan komitmen dan keterampilan yang berbeda dalam pengoperasian teknologi. Belum lagi kebijakan ini agak mendadak untuk belajar dengan teknologi padahal sebelum COVID-19 muncul, guru dan siswa di pelosok belum terbiasa, dan beberapa sekolah melarang siswa membawa alat gadget ke sekolah. Hal ini juga menjadi ironi dalam sistem dan kebijakan pendidikan di daerah terpencil yang sangat kontradiktif dengan kebutuhan pendidik pelaksana dan pembelajaran di era teknologi tinggi jauh sebelum pandemi dan krisis lainnya terjadi.

Rizqon Halal Syah Aji (2020) menyampaikan bahwa dalam keadaan normal, ada banyak perbedaan antar daerah. Kementerian Pendidikan yang diketuai Menteri Nadiem Makarim mencerminkan semangat peningkatan produktivitas siswa dan peningkatan kesempatan kerja sambil kuliah. Namun, dengan merebaknya Covid-19 secara tiba-tiba, pendidikan Indonesia perlu mengikuti arus yang membantu memperbaiki kondisi sekolah dalam keadaan darurat.

Agar proses belajar mengajar tetap berlangsung di masa pandemi covid-19 maka pihak sekolah menerapkan pembelajaran daring. Terdapat kendala pembelajaran online dalam pelaksanaannya. Rintangan pertama bagi anak-anak yang tidak memiliki gadget (HP). Kendala kedua adalah memiliki handphone, namun sulit untuk mengirim perintah karena perangkat handphone dan koneksi internet terhambat dan sinyal lemah. Lebih banyak data menjelaskan bahwa beberapa siswa tidak memiliki ponsel dan harus meminjamnya. Kendala 
ketiga adalah orang tua memiliki handphone, tetapi seharian bekerja di luar rumah, sehingga hanya bisa menemani pada malam hari. Kendala keempat adalah keterbatasan koneksi internet. Beberapa siswa tidak memiliki ponsel dan jaringan internet tidak baik. Kendala keempat adalah tidak semua anak memiliki fasilitas HP dan sebagian orang tua belum memahami teknologi tersebut. Hal ini mempersulit orang tua untuk mendampingi anaknya dan memudahkannya. Kasus seperti ini sangat meresahkan dan guru perlu mengulang pemberitahuan. Kendala keenam adalah pengajar tidak selalu menerima informasi secara langsung karena keterbatasan alokasi internet (Anugrahana, 2020).

Sekolah siap atau tidak siap harus memaksa penggunaan media online. Namun, penggunaan teknologi bukan tanpa masalah. Ada banyak variasi masalah yang menghambat efektivitas metode pembelajaran online seperti keterbatasan pengelolaan teknologi informasi oleh guru dan siswa (Aji, 2020). Semua pemangku kepentingan perlu bersinergi untuk mengelola dampak Covid-19 di dunia pendidikan. Keadaan ini tidak terlepas dari kebijakan pemerintah dan implementasinya di lapangan (Aji, 2020).

Sekolah gereja Advent Banjarmasin menjalankan proses belajar mengajar secara online dengan menggunakan aplikasi zoom dan whatsapp. Sekolah gereja Advent Banjarmasin secara jaringan tidak ada kendala karena terletak di tengah kota. Dimana sekolah telah menggunakan jaringan indihome dari Telkom dan beberapa siswa menggunakan jaringan indihome maupun jaringan seluler pada umumnya. Kendala yang sering dialami oleh siswa disebabkan beberapa siswa tidak memiliki Handpone/ Laptop sendiri, serta penggunaan kuota internet yang banyak. Kendala lain yang dihadapi adalah belum terbiasa belajar secara online, kurang paham dalam menggunakan teknologi secara online baik guru maupun murid serta guru tidak bisa secara langsung mengontrol keseriusan siswa belajar.

Tidak dapat dipungkiri bahwa pandemi covid 19 ini memiliki dampak ekonomi yang luas, di mana hal tersebut termasuk di dunia Pendidikan terhadap pembiayaan operasional sekolah. Semua ini dikarenakan kesulitan keuangan bagi orang tua murid sehingga menunda pembayaran uang sekolah, sementara proses belajar dan mengajar harus tetap dilanjutkan dan disana ada pembiayaan operasional sekolah maupun gaji atau honor guru-guru yang harus diberikan. Penguasaan pembelajaran oleh pengelola dan institusi pendidikan di masa pandemi COVID-19 menjadi tantangan yang cukup berat. Maka, secara khusus, sekolah swasta harus mandiri secara finansial dalam pembiayaan (Dedhez Anggara, 2020). 
Pada survei yang dilakukan oleh Kementerian Pendidikan dan Kebudayaan menunjukkan bahwa sekitar $60 \%$ siswa di sekolah negeri dan swasta menuntut $50 \%$ dari biaya sekolah mereka. Dengan merebaknya Covid-19, beberapa orang tua siswa mengalami kendala keuangan terkait kemampuan mereka untuk membayar uang sekolah. Industri sendiri sangat bergantung pada sekolah swasta, tetapi sebagian besar masih mengandalkan uang sekolah dari siswa (Indira Rezkisari, n.d.).

Sekolah gereja Advent Banjarmasin adalah sekolah swasta yang pembiayaannya adalah mandiri dari pendapatan uang sekolah yang dibayarkan oleh para orang tua siswa. Pada masa pandemic covid 19 ini situasi keuangan orangtua semakin sulit, hal ini berdampak pada penundaan pembayaran uang sekolah. Dengan penundaan pembayaran uang sekolah sangatlah berdampak terhadap keuangan sekolah yang dikelola secara mandiri tersebut. Permasalahan ini mengakibatkan sekolah mengalami kendala dalam proses mengajar untuk meningkatkan mutu pendidikan. Namun sebagai seorang gembala yang terlibat di dalamnya berusaha mendukung dalam motivasi atau memberikan semangat bagi pihak sekolah supaya guru tetap semangat mengajar untuk dapat mencerdaskan anak bangsa maupun memberikan pelayanan bagi anak-anak Tuhan. Motivasi merupakan salah satu komponen penting dalam mengadakan proses pembelajaran di dunia pendidikan (Sahertian et al., 2021, p. 161).

\section{Dampak Positif Di Dunia Pendidikan Akibat Pandemi Covid 19}

Walaupun begitu banyak dampak negative dari pandemi covid 19, namun tidak dipungkiri ternyata ada dampak positifnya yang dapat diterima baik guru sebagai pendidik maupun siswa yang menerima didikan. Matdio Siahaan (2020) menjelaskan bahwa di balik persoalan dan keluhan tersebut juga tampaknya terdapat berbagai pelajaran tentang pendidikan di Indonesia. Diantaranya, siswa dan guru dapat mempelajari teknologi yang mendukung pembelajaran online ini. Di era teknologi yang semakin canggih ini, guru dan siswa perlu memiliki keterampilan di bidang teknologi pembelajaran. Menguasai keterampilan belajar dan belajar yang sangat berbeda merupakan tantangan bagi mereka. Kebijakan Work From Home (WFH) memungkinkan semuanya untuk memaksakan dan mempercepat perolehan teknologi pembelajaran digital. Persyaratan kebutuhan tersebut memungkinkan kita untuk menemukan media online yang dapat mendukungnya sebagai alternatif pembelajaran langsung di kelas tanpa mengurangi kualitas materi pembelajaran atau tujuan pembelajaran. Berbagai metode pembelajaran jarak jauh telah diuji dan digunakan. Fitur-fitur yang tersedia sebagai media pembelajaran online antara lain e-learning, aplikasi zoom, Google Classroom, media sosial YouTube dan WhatsApp. Fasilitas tersebut dapat 
dimanfaatkan secara optimal untuk pembelajaran di kelas. Dengan menggunakan media online tersebut, siswa dan guru secara tidak langsung semakin mengontrol kemampuannya dalam menggunakan dan mengakses teknologi.

Sekolah gereja Advent Banjarmasin berada di tengah kota. Di mana sekolah maupun guru sudah diperlengkapi dengan tekhnologi komputer dan sekolah diperlengkapi dengan jaringan internet yang memadai. Dengan sarana ini memungkinkan untuk dapat melakukan proses mengajar secara online. Walaupun pada awalnya tidak terbiasa namun situasi ini membuat guru harus kreatif mengajar secara online, bukan sekedar memberikan tugas melalui whatsapp tapi juga dapat mengajar secara virtual melalui aplikasi zoom sehingga guru tetap dapat menyampaikan materi dengan bertatap muka walaupun secara virtual. Dikesempatan lain guru juga belajar menggunakan media Youtube sehingga dapat menyampaikan materi video yang terdapat di Youtube.

Dunia pendidikan harus menghasilkan orang-orang berbakat yang dapat mengatasi semua masalah yang dihadapinya di masa depan. Menciptakan manusia yang kredibel dan siap menghadapi tantangan hidup di masyarakat dan memerlukan berbagai strategi yang dapat meningkatkan proses pembelajaran di dunia pendidikan (Ritonga et al., 2021). Ketika pendidik dapat mempelajari berbagai alat pembelajaran online, mereka akan menemukan ide untuk variasi metode dan model pembelajaran yang lebih luas daripada sebelumnya. Misalnya, guru membuat konten video kreatif sebagai alat. Dalam hal ini, guru menjadi lebih kreatif karena siswa menjadi lebih tertarik dengan materi yang diberikan guru melalui video kreatif. Tidak diragukan lagi bahwa siswa akan dapat memahami apa yang dijelaskan oleh guru melalui video kreatif yang dibuat oleh guru (Puspitasari, 2020). Berbagai metode pembelajaran guru memungkinkan untuk membuat produk pembelajaran kreatif yang mengembangkan pemikirannya melalui analisis, tanpa meninggalkan topik yang dikomunikasikan oleh setiap guru (Puspitasari, 2020). Adanya pandemi covid-19 tidak sepenuhnya memiliki dampak buruk, namun juga dapat memberikan hikmah.

Pembelajaran di rumah dapat memudahkan orang tua untuk secara langsung mengontrol atau mengawasi perkembangan belajar anaknya. Lebih mudah bagi orang tua untuk mengajar dan memantau pembelajaran anak-anak mereka di rumah. Ini mengarah pada komunikasi yang lebih kuat dan hubungan yang lebih dekat antara anak dan orang tua. Orang tua dapat mengajari anaknya secara langsung tentang materi pembelajaran yang belum dipahaminya. Padahal, orang tua adalah institusi pertama dalam pendidikan anak. Kegiatan pembelajaran online yang disediakan oleh guru memungkinkan orang tua untuk memantau 
Janes Sinaga, Rudolf Weindra Sagala, Rolyana Ferinia, Stimson Hutagalung.

kemampuan dan derajat kemampuan anaknya. Ketidakjelasan materi yang diberikan guru membuat komunikasi antara orang tua dan anak semakin rumit. Orang tua dapat membantu mengatasi masalah serius yang dihadapi anak-anak saat mengikuti proses pembelajaran (Siahaan, 2020).

Dengan demikian, dibalik hal-hal yang negative dan kesulitan-kesulitan yang dihadapai oleh guru, orang tua, maupun siswa, masih ada dampak positif yang harus disadari. Dampak positif harus lebih ditingkatkan dalam ruang lingkup pendidikan di masa Pandemi Covid 19 ini.

\section{Peranan Gembala Terhadap Guru-Guru Sekolah Gereja}

\section{Dukungan Gembala Jemaat Pada Guru}

Kewajiban seorang gembala sebagaimana kapasitasnya yaitu membantu anggota jemaat termasuk guru-guru. Semua tindakan penggembalaan dalam pelayanan pastoral yang dilakukan gembala kepada anggota jemaat dan guru-guru merupakan tindakan yang membantu jemaat untuk menyembah Tuhan yang benar dan hidup dalam setiap aspek kehidupanNya (Hutagalung et al., 2021). Gembala dapat melakukan pelayanan pastoral kepada jemaat dan juga guru. Hutagalung (2021) menuliskan ada beberapa pelayanan pastoral yang dapat dilakukan seorang gembala. Adapun bentuk pelayanan pastoral meliputi: 1. Merawat mereka yang berada dalam krisis atau keadaan stress yang hebat termasuk dimensi fisik, spiritual, emosional dan mental. 2. Mendukung mereka yang sedang menjalani masalah tantangan yang besar. 3. Membimbing untuk menjawab pertanyaan atas masalah hidup. 4. Mengatasi kebutuhan melalui penyembuhan jiwa, dan rekonsiliasi dari hubungan yang rusak. Seorang gembala dapat melakukan pelayanan pastoral tersebut juga kepada guruguru dan siswa sebagai bagian dari anggota jemaat setempat.

Adanya sekolah gereja disatu jemaat tidak lepas dari tanggung jawab seorang gembala. Pendeta jemaat harus menjadi anggota dewan sekolah. Jika sekolah dijalankan oleh banyak jemaat, pendeta jemaat biasanya adalah anggota dewan sekolah (Peraturan Jemaat Gereja Masehi Advent Hari Ketujuh, 2011, p. 120). Ketika gembala jemaat menjadi anggota majelis sekolah maka akan memiliki kesempatan yang luas untuk memberikan pandangan, dukungan terhadap kemajuan sekolah.

Pedoman Kependetaan gereja Advent menuliskan bahwa tanggung jawab seorang gembala atau pendeta yaitu mendukung guru-guru sekolah gereja. Para pendeta dan para guru bermitra dalam pelayanan. Para pendeta harus terlibat dalam urusan sekolah, tetapi tidak 
boleh mencampuri atau menolak program guru. Orang-orang tua dalam sekolah gereja terkadang merasa mempunyai otoritas istimewa atas guru-guru (Kependetaan \& Ketujuh, 2003, p. 152).

Ada beberapa hal yang dapat dilakukan seorang gembala jemaat bagi sekolah, apalagi sekiranya gembala memiliki kecakapan dalam satu bidang maka dapat membantu guru yang tidak cakap dalam hal tersebut. Dalam situasi pandemi ini boleh jadi guru-guru kesulitan beradaptasi dengan metode pengajaran daring. Sekiranya gembala memiliki keahlian dalam hal ini tentu saja seorang gembala dapat memberikan masukan dan bimbingan dalam penggunaan tekhnologi.

\section{Gembala Mendoakan Guru-Guru}

Setiap aspek kehidupan yang dilalui sebagai umat Tuhan, doa adalah andalan. Doa adalah cara untuk mencari pertolongan-Nya dalam situasi apa pun. Tentu saja, Tuhan ingin membantu umat-Nya menghadapi dunia ini. Tetapi, seperti yang Yesus tunjukkan, Tuhan ingin kita mencari pertolongan-Nya melalui doa. Doa adalah alat untuk mencari pertolongan Tuhan dalam hidup ini (Laoly, 2020). Salah satu peran gembala yaitu menjadi gembala yang sejati, mencakup perantaraan tindakan pelayanan doa yang terus menerus, memohon doa untuk diri sendiri, doa untuk kawanan domba yang ada di kandang, dan doa untuk domba yang hilang. Melalui doa seperti itu, dengan semangat, gembala dapat setia dalam pekerjaan (Hutagalung et al., 2021). Guru sekolah gereja merupakan anggota jemaat, untuk itu adalah tanggungjawab gembala untuk mendoakan para guru sekolah gereja.

Alkitab dengan jelas menyatakan bahwa doa dan iman adalah jawaban atas semua kebutuhan dan masalah hidup. Seperti yang terdapat dalam surat Rasul Paulus: "Janganlah hendaknya kamu kuatir tentang apa pun juga, tetapi nyatakanlah dalam segala hal keinginanmu kepada Allah dalam doa dan permohonan dengan ucapan syukur." (Filipi 4:6). Hal yang serupa dengan demikian juga terdapat dalam kitab-kitab lainnya, seperti pemazmur yang menyatakan bahwa Tuhan sangat memperhatikan setiap seruan umat-Nya (Mazmur 34:16).

Guru mempunyai pergumulun yang cukup berat dalam menghadapi murid-muridnya dalam hal mengajar, mendisiplin maupun hubungan dengan orang tua murid dan masalah lainnya. Guru perlu mendapatkan bimbingan, penghiburan dan kekuatan rohani dari seorang gembala. Demikian juga dalam situasi krisis ekonomi sebagai dampak Pandemi covid 19 guru-guru boleh jadi akan terlambat menerima gaji bulanan. Hal ini berdampak pada 
kehidupan sehari-hari. Maka, mereka perlu didukung dan didoakan agar tetap bersemangat dalam menjalankan tugas dan tanggungjawabnya di sekolah gereja.

\section{Membantu dalam Pengajaran di Sekolah}

Seorang gembala jemaat haruslah memiliki hubungan yang erat dengan sekolah gereja terutama dalam pembinaan kerohanian. Gembala jemaat di Gereja Masehi Advent Hari Ketujuh diharuskan sudah menyelesaikan pendidikannya sebagai Sarjana Theologia di Universitas maupun Perguruan Tinggi. Dengan demikian gembala jemaat di Gereja Advent sudah pasti memiliki kemampuan untuk mengajar Pendidikan Agama Kristen.

Pada buku pedoman kependetaan kembali menuliskan apa yang harus dibuat seorang gembala di sekolah gereja:

"Ikutilah kebaktian bersama, mungkin sekali seminggu. Buatlah jadwal supaya engkau kadang-kadang ikut bermain di tempat bermain. Engkau bisa bergaul lebih rapat dengan para guru dan siswa di sana. Jika engkau mempunyai kebolehan dalam atletik, kehormatan yang engkau peroleh di tempat bermain akan berdampak pada pekabaran yang engkau sajikan di kelas maupun di mimbar. Keberhasilanmu mengubah sikap orang terhadap Yesus tergantung lebih besar pada apa yang engkau pikirkan pada waktu mengatakannya dari pada apa yang engkau katakan mengenai Dia (Kependetaan \& Ketujuh, 2003).”

Hal ini menyatakan pentingnya keterlibatan seorang Pendeta sebagai seorang gembala jemaat dimana sekolah gereja berada.

\section{Membantu Mengatasi Kesulitan Finansial}

Sekolah gereja adalah sekolah swasta dimana pembiayaannya adalah secara mandiri. Seringkali sekolah memiliki kesulitan membiayai operasional sekolah. Walaupun ada sarana bantuan dari pemerintah melalui dana BOS namun semua itu tidak dapat mencukupi pembiayaan operasional sekolah. Maka, diperlukan bantuan dari gereja, donator maupun anggota jemaat. Gembala jemaat dapat menjadi mediator atau penghubung dalam hal tersebut. Gembala juga memahami kebutuhannya, mendampingi kawanan domba dengan penuh kesabaran saat dia melengkapi mereka untuk membuat keputusan yang bijaksana dan meningkatkan kehidupan.

Uang pembayaran sekolah digunakan untuk membayar gaji guru-guru. Beberapa dari mereka duduk dalam dewan sekolah yang menggaji guru- guru. Sebagai anggota gereja, mereka merasa bahwa sekolah itu adalah milik mereka. Pendeta, bersama-sama dengan dewan sekolah, harus melindungi guru-guru dari gangguan orang-orang tua murid. Pendeta 
mempunyai peran rangkap, yaitu sebagai pendeta dan juga sebagai orang tua (Kependetaan \& Ketujuh, 2003).

Terkadang dalam situasi normal sekolah masih menghadapi kesulitan dalam hal keuangan. Sudah tentu dalam situasi masa pandemi covid 19 sumber pendapatan dari orang tua murid terkendala karena krisis ekonomi. Gembala bisa menjadi penghubung untuk mencarikan donatur baik dari iuran gereja maupun mencari donator secara personal untuk mendukung pembiayaan operasional sekolah. Sebagai seorang gembala yang adalah pemimpin dalam gereja dimana sekolah berada dapat mengajukan kepada majelis gereja untuk membantu biaya operasional sekolah. Hal lain yang dapat dilakukan seorang gembala adalah mencarikan donator secara perorangan baik dari kenalan pribadi maupun dari anggota jemaat yang murah hati untuk membantu biaya operasional sekolah. Gembala jemaat dapat mencarikan beasiswa bagi siswa yang kesulitan untuk membayar uang sekolahnya. Kehadiran sosok gembala diharapkan dapat membantu dalam hal operasional sekolah.

\section{Mengadakan Ibadah Singkat dan Berdoa Diawal Kelas}

Di dalam memulai setiap kelas pada pagi hari setiap siswa diajak untuk mengadakan ibadah singkat terlebih dahulu sebelum mengikuti setiap jam-jam pelajaran di ruang-ruang kelas, dengan tujuan agar para siswa dilatih untuk selalu mendekatkan diri kepada Tuhan, belajar untuk beribadah dan menyembah Tuhan, mengutamakan Tuhan dalam segala hal. Ketika mereka mendengar kata "ibadah", kebanyakan orang mengaitkannya dengan ritual formal yang ketat, membosankan, dan tidak menarik. Akibatnya, banyak keluarga menyebut diri mereka keluarga Kristen, tetapi mereka jarang atau tidak pernah memiliki persekutuan dengan keluarga mereka sendiri (Junim \& Sagala, 2020). Ibadah dalam keluarga dapat menjadi kegiatan rutinitas setiap hari yang dilakukan sebagai seorang Kristen, namun kesempatan ini boleh jadi dilewatkan. Oleh sebab itu keluarga harus dapat menciptakan pengenalan awal akan janji Allah yang mengasihi dan berkorban bagi semua manusia (Ristiono \& Sirait, 2021, p. 188). Di sekolah gereja kegiatan ibadah adalah suatu hal yang wajib dilakukan setiap hari sebelum materi pelajaran diajarkan. Kegiatan ibadah tersebut juga mengundang keterlibatan para siswa sehingga tidak membosankan.

Firman Tuhan menuliskan bahwa pentingnya beribadah sebelum memulai kegiatan keseharian kita. Markus 1:35 "Pagi-pagi benar, waktu hari masih gelap, Ia bangun dan pergi ke luar. Ia pergi ke tempat yang sunyi dan berdoa di sana." Selanjutnya dalam kitab Matius 6:33 mengatakan: "Carilah dahulu kerajaan Allah dan kebenarannya maka semuanya itu akan 
Janes Sinaga, Rudolf Weindra Sagala, Rolyana Ferinia, Stimson Hutagalung.

di tambahkan kepadamu" Para murid tidak hanya diajarkan untuk berdoa, tetapi mereka juga diajarkan bagaimana berdoa, mendekati Sang Pencipta, menjalankan iman kepada-Nya, dan memahami serta menaati ajaran-ajaran rohani-Nya (Ellen G. White, 2005b). Ibadah adalah wujud terimakasih, mendahulukan Tuhan dan penyertaan Tuhan di dalam segala rutinitas keseharian.

Ketika seorang gembala adalah anggota majelis sekolah gereja maka akan memiliki peran dalam memajukan sekolah dan kerohanian siswa maupun guru. Seorang gembala dapat menghimbau guru agar selalu mengutamakan Tuhan dalam praktek pendidikan, hal ini dapat dilakukan agar selalu membuat ibadah singkat sebelum dimulainya pelajaran. Pada saat seorang gembala juga terlibat sebagai tenaga pengajar dalam Pendidikan Agama Kristen maka gembala dapat memimpin langsung ibadah singkat dan memberi pendidikan bagaimana melakukan ibadah yang baik dan benar serta berkesinambungan bagi siswa yang didiknya. Dengan memberikan pendidikan tersebut maka anak-anak murid akan diajarkan untuk memiliki kebiasaan beribadah maupun berdoa sebelum memulai aktifitas di rumah maupun di sekolah.

\section{Mengadakan Pembacaan Alkitab Sebagai Literasi}

Sebagai seorang Kristen membaca Alkitab adalah rutinitas yang tidak bisa diabaikan serta wajib dilakukan walaupun seorang pelajar. Membaca Alkitab merupakan pelajaran wajib sebagai renungan harian orang Kristen. Sebab tanpa membaca Alkitab, kehidupan rohani Kristen akan kering dan berhenti untuk bertumbuh. Membaca Alkitab sangatlah penting karena Alkitab adalah Firman Tuhan. Oleh karena membaca Alkitab itu sangatlah penting, maka anak-anak Kristen harus dibimbing untuk membaca Alkitab secara benar dan bertanggung jawab (Marthen Mau, Saenom, 2021).

Pengajaran di sekolah gereja sesuai dengan perangkat pengajaran kurikulum 2013, maka setiap sekolah di wajibkan untuk mengawali setiap jam pelajaran pada jam pertama yaitu 15 menit pertama dengan literasi. Maka pada jam literasi tersebut di sekolah gereja diterapkan kepada para peserta didik untuk membaca Alkitab sebagai buku bacaan utama, dan setiap siswa diwajibkan membawa Alkitabnya masing-masing dari rumah di setiap hari jam pelajaran. Menurut Hutagalung (2014) begitu seseorang bangun di pagi hari, dia menghadapi pengambilan keputusan dan dihadapkan dengan keputusan yang sulit tentang cara hidup. Misalnya, bagaimana seseorang membuat keputusan yang tepat, terutama ketika 
berhadapan dengan masalah moral dan etika. Sebelum siswa menerima pelajaran yang lain mereka harus terlebih dahulu dibekali dengan Firman Tuhan.

Tujuan membaca Alkitab supaya para siswa lebih mencintai Alkitab, menjadikan Alkitab sebagai buku pedoman dan penuntun hidup kerohanian. Melalui membaca Alkitab para peserta didik mendapat pengetahuan bahwa Alkitab adalah sumber yang benar dan para siswa tidak terpengaruh dengan teori-teori ilmu pengetahuan yang kadang kala berlawan dengan Alkitab, seperti kisah penciptaan dunia. Selanjutnya para siswa harus lebih rajin membaca serta memahami maksud-maksud Tuhan dalam pembentukan karakter dan tabiat hidup yang sesuai dengan Firman Tuhan.

Pembentukan tabiat harus terus dilakukan disetiap kesempatan. Yesus mempelajari Alkitab di masa kanak-kanak, remaja, dan dewasa. Ketika Dia masih kecil, ibunya belajar dari buku-buku Nabi dan berdoa setiap hari. Ketika Dia masih muda, di pagi buta dan jamjam redup, Ia dapat ditemukan sendirian di pegunungan dan di pepohonan hutan sambil diamdiam menghabiskan waktu berdoa dan mempelajari Firman Tuhan. Selama misi-Nya, perolehan Alkitab menunjukkan kemampuannya untuk mempelajari buku. Karena Dia telah memperoleh pengetahuan yang dapat kita peroleh, kekuatan ajaib menjadi bukti dari nilai Alkitab sebagai segudang pendidikan, baik secara rohani maupun duniawi (Ellen G. White, 2005b). Pembentukan tabiat atau karakter tidak terjadi begitu saja namun sebuah proses dari waktu-kewaktu. Yesus adalah Tuhan tetapi semasa hidup-Nya di dunia mempelajari Firman Tuhan maka sebagai pengikutnya haruslah mencontoh Yesus.

Dengan dibiasakannya anak murid membaca Alkitab sebagai Firman Tuhan maka mereka akan mencintai Firman Tuhan dan akan lebih bijaksana dalam bertindak: "Betapa kucintai Taurat-Mu! Aku merenungkannya sepanjang hari. Perintah-Mu membuat aku lebih bijaksana dari pada musuh-musuhku, sebab selama-lamanya itu ada padaku (Mazmur 119:9798). Lebih lanjut Firman Tuhan menuliskan pentingnya membaca Alkitab secara rutin: "Janganlah engkau lupa memperkatakan Kitab Taurat ini, tetapi renungkanlah itu siang dan malam, supaya engkau bertindak hati-hati sesuai dengan segala yang tertulis di dalamnya, sebab dengan demikian perjalananmu akan berhasil dan engkau akan beruntung (Yosua 1:8)." Selanjutnya Musa memberikan tuntunan yang sangat jelas tentang menjadi orang yang bahagia dalam mengantisipasi janjinya. Musa menasihati supaya memperkatakannya berulang-ulang (Ulangan 6:7). Ini adalah perintah dan tidak dapat dinegosiasikan. Artinya, kita tidak bisa memilih (Hutagalung, 2014). 
Membaca Alkitab dapat menuntun para murid di sekolah untuk memiliki tingkah laku yang lebih baik sebagaimana dituliskan oleh Firman Tuhan: "Segala tulisan yang diilhamkan Allah memang bermanfaat untuk mengajar, untuk menyatakan kesalahan, untuk memperbaiki kelakuan dan untuk mendidik orang dalam kebenaran (2 Timotius 3:16)." Pengaruh kuasa Firman Tuhan sangatlah luar biasa, dapat mengubah serta menguatkan hidup seseorang. Petunjuk kehidupan dalam Alkitab selalu relevan dengan kehidupan manusia dari dulu hingga sekarang (Hutagalung \& Ferinia, 2020).

Melalui program membaca Alkitab setiap hari akan menuntun anak-anak murid menjadi seorang yang takut akan Tuhan dan mencintai Tuhan. Gembala sebagai guru Pendidikan Agama Kristen dapat membuat program membaca Alkitab satu pasal setiap hari di rumah, agar program ini dapat berlangsung dengan baik harus ada cek validasi dari orang tua sebagai pengawas di rumah dan tugas ini akan di validasi kembali oleh guru atau wali kelasnya di sekolah. Gembala sebagai guru agama Kristen juga dapat menerapkan keharusan membaca Alkitab di sekolah sebagai bahan materi utama pelajaran Agama Kristen agar setiap pengajaran tidak menyimpang dari buku utama yaitu Alkitab. Dengan melakukan program pembacaan Alkitab maka anak-anak murid akan dikembangkan kecintaannya membaca Alkitab yang adalah Firman Tuhan.

\section{REKOMENDASI PENGEMBANGAN PENELITIAN}

Artikel ini dapat dikembangkan melalui pembahasan topik tentang kepuasan semua elemen di Sekolah Gereja. Peneliti berharap kiranya artikel ini dapat menjadi sumber rujukan bagi para peneliti berikutnya. Kiranya dengan artikel ini Gereja, jemaat dan para peneliti dapat terbantu dalam upaya memahami peran fundamental gembala bagi guru di masa pandemik.

\section{KESIMPULAN}

Kehadiran Gembala di lingkungan Sekolah dapat menjalankan peranannya untuk membimbing dan mengingatkan guru-guru agar tetap dalam misi Pendidikan yang benar, yaitu mengembalikan citra Allah. Gembala juga dapat menjalankan perannya dalam membantu guru di sekolah gereja dengan mengajar Pendidikan Agama Kristen. Gembala juga dapat menguatkan guru-guru melalui doa bersama dan memberikan motivasi ketika mengalami keadaan depresi maupun permasalahan lainnya yang dihadapi sesuai kemampuan maupun kapasitas sebagai seorang gembala jemaat. 
Gembala dapat menjadi penyokong kemajuan sekolah gereja melalui pemikiran, motivasi dan penghubung kepada orangtua maupun Gereja. Dikarenakan seorang gembala mempunyai akses yang luas di gereja, dimasyarakat maupun disekolah, maka kesempatan ini dapat digunakan dalam mendukung kemajuan sekolah dalam hal keuangan sekolah untuk memenuhi operasional sekolah dan hal ini sangat dibutuhkan terutama dimasa pandemic covid 19. Pada umumnya sekolah mengalami dampak kesulitan keuangan, disinilah gembala dapat menjalankan perannya dalam membantu mencarikan jalan keluar agar sekolah tetap beroperasi tanpa kendala. Sekiranya gembala menjalankan perannya dalam membantu sekolah gereja maka sekolah gereja sangat terbantu dalam pengembangan pendidikan karakter siswa, memotivasi guru dan keberlangsungan kemajuan sekolah.

\section{BIODATA}

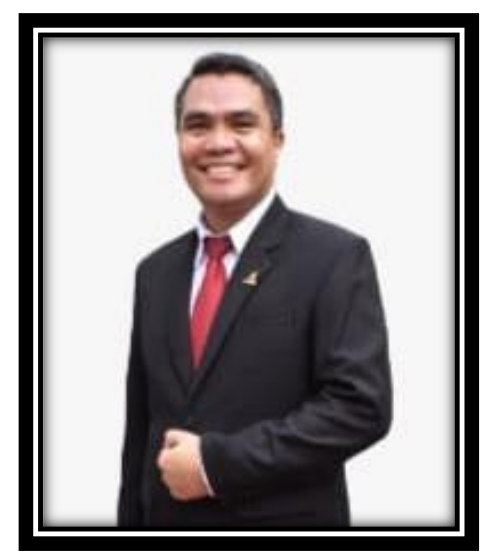

Janes Sinaga adalah seorang Gembala Jemaat Gereja Masehi Advent Hari Ketujuh (GMAHK) Banjarmasin dan penulis juga adalah seorang guru Pendidikan Agama Kristen di SD - SMP Advent Banjarmasin. Pada saat ini sedang mengikuti Pendidikan Pasca Sarjana di Universitas Advent Indonesia Bandung. Tulisan-tulisan sementara dibuat meliputi Kepemimpinan, Peran Gembala jemaat bagi sekolah dan karakter anak-anak, Tulisan ini kiranya dapat berguna dikemudian hari untuk kemajuan sekolah-sekolah Kristen dimanapun.

\section{Janes Sinaga}

J1. Pulau Laut RT 06, Banjarmasin Tengah, Kota Banjarmasin, Kalimantan Selatan. Surel: janessinaga777@gmail.com

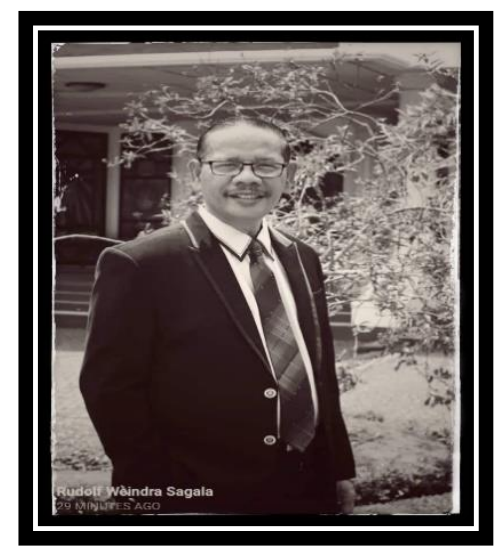

Dr. Rudolf Weindra Sagala, Lahir 21 Januari 1961 di Indrapura Asahan. Saat ini adalah seorang Dosen di Universitas Advent Indonesia (UNAI), Bandung. Pernah menjadi Pembantu Ketua 3 Bidang Kemahasiswaan dan Ketua Perguruan Tinggi Advent Surya Nusantara (PTASN), Pematang Siantar. Saat ini bekerja sebagai Dosen di UNAI, Bandung dan mengajar Mata kuliah: Daniel dan Wahyu, Pelayanan Penggembalaan, Liturgika, Doktrin Alkitab, Greek, Perbandingan Agama, Pertumbuhan Gereja dan beberapa Mata Kuliah lainnya. Menamatkan Doctor of Ministry dari AIIAS, Philippines pada tahun 2001.

\section{Dr. Rudolf Weindra Sagala}

UNAI, Jl. Kolonel Masturi 288, Parompong, Bandung Barat.

Surel: rsagala@gmail.com 


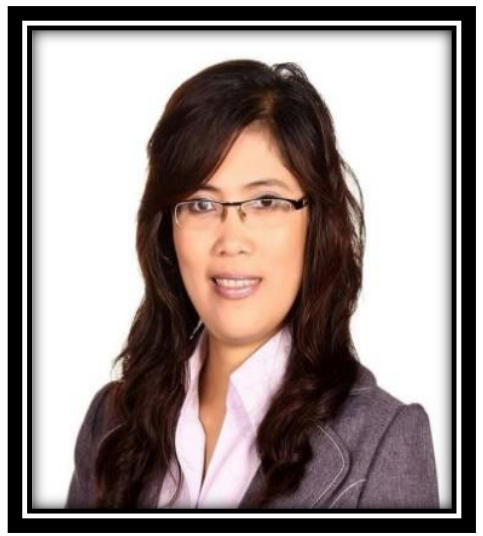

Dr. Rolyana Ferinia adalah Dosen di Fakultas Ekonomi. Ketua Jurusan sekretaris, Dekan Fakultas Ekonomi, Dosen Fakultas Ekonomi, Konsultan HR, Reviewer di Scientific Article In Journal Of Management (Telkom University), Reviewer di Journal of Management and Business Sekolah Tinggi Makassar, Reviewer di Internasional Seminar \& Conference on Learning Organization ke 6. Menyelesaikan Studi S1 Ekonomi 1993 san S2 Manajemen 2009 di Universitas Advent Indonesia, pada tahun 2016 beliau menyelesaikan Pendidikan Doktoral ilmu manajemen di Universitas Pendidikan Indonesia. Saat ini ia aktif menulis di jurnal dan buku-buku serta penelitian.

\section{Dr. Rolyana Ferinia}

UNAI, Jl. Kolonel Masturi 288, Parompong, Bandung Barat.

Surel: rolyana.pintauli@unai.edu

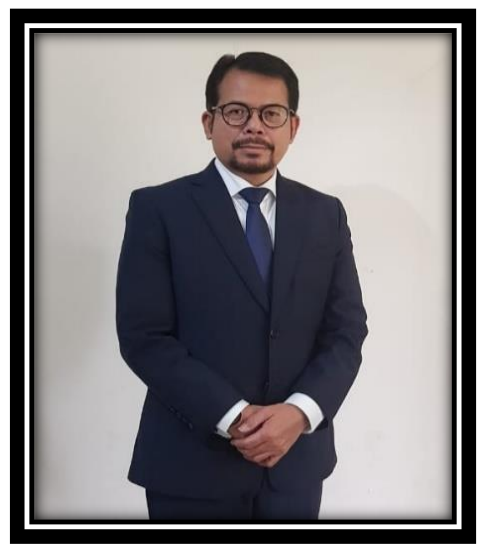

Dr. Stimson Hutagalung, Lahir di Tanah Jawa pada tahun 1967. Beliau merupakan dosan di Fakultas Filsafat, Direktur bimbingan dan Konseling, Direktur Pasca Sarjana, Kaprodi Magister Filsafat, Editorial Board Klabat Theological, Riviewer Jurnal Koinonia. Menyelesaikan Pendidikan sarjana (1990) dan Pendidikan Magister (2007) di Universitas Advent Indonesia, lalu beliau menyelesaikan Program Doktoral di STT Jakarta pada tahun 2014. Tulisan-tulisan yang dia buat mengenai Penggembalaan Jemaat, Pertumbuhan Gereja dan Pastoral Konseling.

\section{Dr. Stimson Hutagalung}

UNAI, Jl. Kolonel Masturi 288, Parompong, Bandung Barat.

Surel: stimson.hutagalung@unai.edu

\section{REFERENSI}

Aji, R. H. S. (2020). Dampak Covid-19 pada Pendidikan di Indonesia: Sekolah, Keterampilan, dan Proses Pembelajaran. SALAM: Jurnal Sosial Dan Budaya Syar-I, 7(5), 395-402. https://doi.org/10.15408/SJSBS.V7I5.15314

Anugrahana, A. (2020). Hambatan, Solusi dan Harapan: Pembelajaran Daring Selama Masa Pandemi Covid-19 Oleh Guru Sekolah Dasar. Scholaria: Jurnal Pendidikan Dan Kebudayaan, 10(3), 282-289. https://doi.org/10.24246/J.JS.2020.V10.I3.P282-289

Dawa, M. D. L. (2020). Gembala Cendikiawan: Sebuah Gambaran Tentang Gembala Jemaat. Te Deum, 10(1), 83-105.

Dedhez Anggara. (2020). Pandemi covid-19 akan mempengaruhi pengelolaan pendidikan dan sekolah. Nasional.Kontan.Co.Id. 
Ellen G. White. (2005a). Kesaksian bagi Sidang. Indonesia Publishing House.

Ellen G. White. (2005b). Pendidikan Sejati. Indonesia Publishing House.

Gunter, N. H. (2018). The shepherd-leader motif as a pastoral model for a globalizing church. Perichoresis, 16(3), 87-105. https://doi.org/10.2478/perc-2018-0018

Herawati, K. (2016). Pentingnya Pendidikan Agama Kristen (PAK) Bagi Etiket Pergaulan Anak. SCRIPTA: Jurnal Teologi Dan Pelayanan Kontekstual, 2(2), 56-67. https://doi.org/10.47154/SCRIPTA.V2I2.20

Hutagalung, S. (2014). Firman Tuhan: Pelita Dan Pedang Bermata Dua. Jurnal Koinonia, 6(2), 1-14.

Hutagalung, S. (2021). Pendampingan Pastoral: Teori dan Praktik. Medan: Yayasan Kita Menulis.

Hutagalung, S., \& Ferinia, R. (2020). Menjelajahi Spiritualitas Milenial: Apakah Membaca Alkitab, Berdoa, dan Menghormati Acara di Gereja Menurun? Jurnal Teruna Bhakti, 2(2), 97. https://doi.org/10.47131/jtb.v2i2.50

Hutagalung, S., Nainggolan, B. D., Hendriks, A. C., Walukouw, Y. R., Hutabarat, R., Karosekali, E., Manurung, F., Joseph Hamonangan Sianipar, M. S., Hutabarat, M. S., \& Sagala, R. W. (2021). Konseling Pastoral. Medan: Yayasan Kita Menulis.

Indira Rezkisari. (n.d.). 56 Persen Sekolah Swasta Kesulitan Akibat Covid-19| Republika Online.

Jolf John Tendean, Bartholomeus Diaz Nainggolan, S. H. (2021). Pandemic Covid-19, Health Literature and Great Commission | GRAFTA: Journal of Christian Religion Education and Biblical Studies. GRAFTA: Journal of Christian Religion Education and Biblical Studies, 1(1).

Junim, A. J., \& Sagala, R. W. (2020). Persepsi Anggota Gereja Masehi Advent Hari Ketujuh Jemaat Mangkupa Kota Marudu, Sabah, Malaysia Tentang Implikasi Persembahan Korban Pagi Dan Petang Dalam Ibadah Keluarga Bagi Kehidupan Kristen Berdasarkan Keluaran 29:41-42. Jurnal Koinonia, 12(1), 71-95.

Kependetaan, A., \& Ketujuh, P. P. G. M. A. H. (2003). Pedoman Kependetaan Gereja Masehi Advent Hari Ketujuh. Indonesia Publishing House.

Laoly, N. G. (2020). Kajian Biblika, Sistematika dan Misi tentang Pentingnya Doa Bagi Gereja. IMMANUEL: Jurnal Teologi Dan Pendidikan Kristen, 1(1), 18-24. https://doi.org/10.46305/IM.V1I1.7

Marthen Mau, Saenom, F. F. (2021). Peranan Membaca Alkitab Terhadap Kecerdasan Spiritual Anak Kristen. CARAKA: Jurnal Teologi Biblika Dan Praktika.

Nadeak, E. H. (2017). Karakteristik Pendidikan yang Menebus di Suatu Sekolah Kristen [The Characteristics of Redemptive Education In a Christian School] | Nadeak | Polyglot: Jurnal Ilmiah. Universitas Pelita Harapan, 87-98.

Nadeak, E. H., \& Hidayat, D. (2017). Karakteristik Pendidikan yang Menebus di Suatu Sekolah Kristen [The Characteristics of Redemptive Education In a Christian School]. Polyglot: Jurnal Ilmiah, 13(2), 87-98. https://doi.org/10.19166/PJI.V13I2.439

Peraturan Jemaat Gereja Masehi Advent Hari Ketujuh. (2011). Indonesia Publishing House.

Puspitasari, R. (2020). Hikmah pandemi Covid-19 bagi pendidikan di Indonesia. IAIN Surakarta, 1. 
Rifai, R. (2021). Refleksi Teologis terhadap Tingkat Stress Guru selama Pandemi Covid-19. DUNAMIS: Jurnal Teologi Dan Pendidikan Kristiani, 5(2), 396-407. https://doi.org/10.30648/DUN.V5I2.458

Ristiono, Y. B., \& Sirait, J. R. (2021). Refleksi Teologi Kovenan Berdasarkan Kejadian 1-3 dan Implikasinya bagi Kehidupan Orang Percaya Masa Kini. Ejournal.Sttkb.Ac.Id, 1(1), 186-200. https://ejournal.sttkb.ac.id/index.php/kadesibogor/article/view/9

Ritonga, N., Mone, J. L. T., Yunip, M., \& Zega, Y. K. (2021). Implementasi Metode Problem Solving Dalam Meningkatkan Pembelajaran Pendidikan Agama Kristen Di Sekolah. Jurnal Shanan, 5(1), 29-42. https://doi.org/10.33541/SHANAN.V5I1.2622

Rummage, A. J. (2005). Liberty Baptist Theological Seminary a Model for Pastoral Care and Shepherding Ofa Large and Growing Church.

Sahertian, N. L., Ming, D., Istinatun, H. N., \& Sirait, J. R. (2021). Penerapan Model Pembelajaran Jerold E KEM Di Smp Hanuru. Jurnal Pendidikan Agama Kristen (JUPAK), 2(1), 143-165. https://doi.org/10.52489/jupak.v2i1.26

Siahaan, M. (2020). Dampak Pandemi Covid-19 Terhadap Dunia Pendidikan. Jurnal Kajian Ilmiah, 1(1), 73-80. https://doi.org/10.31599/JKI.V1I1.265

Siew, Y. M. (2013). Pastor as Shepherd-Teacher: Insiders' Stories of Pastoral and Educational Imagination. Christian Education Journal: Research on Educational Ministry, 10(1), 48-70. https://doi.org/10.1177/073989131301000104

Simamora, N. N. (2021). Hakikat dan Tujuan Sekolah Kristen. TE DEUM (Jurnal Teologi Dan Pengembangan Pelayanan), 4(1), 1-23. https://doi.org/10.51828/td.v4i1.74

Sunarko, A. S. (2021). Fungsi Keluarga dalam Persepektif Alkitab sebagai Basis Pendidikan Agama Kristen. Jurnal Pendidikan Agama Kristen (JUPAK), 1(2), 92-107. https://doi.org/10.52489/JUPAK.V2I1.15

Teddy Meilwansyah. (2020). Pembelajaran di Masa Pandemi Covid-19. Dinas Pendidikan Pemerintah Kabupaten Ogan Komering Ulu.

Wahyuningsih, K. S. (2021). Problematika Pembelajaran Daring Di Masa Pandemi Covid-19 Di Sma Dharma Praja Denpasar. Jurnal Pangkaja, 24(1), 107-118.

Weinata Sairin. (2006). Identitas dan Ciri Khas Pendidikan Kristen di Indonesia Antara Konseptual dan Operasional. BPK Gunung Mulia.

White, E. G. (2005). Membina anak yang bertanggung jawab. Indonesia Publising House. 